\title{
EFFECTS OF FABRICATION PARAMETERS ON THE OXIDATION RESISTANCE OF WOOD/PHENOLIC RESIN CARBON COMPOSITES
}

\author{
VPLIV PARAMETROV IZDELAVE NA OKSIDACIJSKO \\ ODPORNOST OGLJIKOVIH KOMPOZITOV NA OSNOVI LESA IN \\ FENOLNE SMOLE
}

\author{
Yubo Tao, Peng Li* \\ College of Material Science and Engineering, Northeast Forestry University, no. 26 Hexing Road, Xiangfang District, Harbin 150040, \\ Heilongjiang, China \\ Prejem rokopisa - received: 2018-10-05; sprejem za objavo - accepted for publication: 2018-12-20
}

doi: $10.17222 /$ mit.2018.216

\begin{abstract}
The oxidation resistance of wood/phenolic-resin carbon composites (woodceramics) in air was investigated from room temperature to $700{ }^{\circ} \mathrm{C}$ by the simultaneous thermogravimetry and differential scanning calorimetry (TG-DSC) analysis. The elementary analysis, Fourier transform infrared spectroscopy (FTIR), and X-ray diffraction (XRD) were utilized to characterize the woodceramics samples prepared with different weight ratios of wood powder to phenolic resin (PF) and carbonized under $800{ }^{\circ} \mathrm{C}, 1000{ }^{\circ} \mathrm{C}$, and $1400{ }^{\circ} \mathrm{C}$. The elementary analysis revealed that the higher carbonization temperature contributed to a higher carbon content, whereas the higher ratio of PF led to a lower carbon content in the samples. The FTIR results showed that the higher carbonization temperature was beneficial to a more regular carbon structure, which was further proven by XRD. The TG-DSC analysis demonstrated that the oxidation resistance of woodceramics increased with the rise of carbonization temperature, which was due to the development of graphitization of woodceramics under a higher carbonization temperature. However, the increased ratio of PF did not bring apparent improvements to the oxidation resistance of the samples. The apparent activation energy was high at the intial reaction stage, and then decreased with the development of thermal degradation, which indicated that more energy was consumed for the completion of the oxidation reactions at the start stage. This study showed that the developed woodceramics exhibited good oxidation resistance in air below $300{ }^{\circ} \mathrm{C}$.
\end{abstract}

Keywords: woodceramics, oxidation resistance, TG, DSC

Avtorja opisujeta raziskavo oksidacijske odpornosti ogljikovih kompozitov na osnovi lesa in fenolne smole (angl.: woodceramics) na zraku pri sobni in povišanih temperaturah (do $700{ }^{\circ} \mathrm{C}$ ). Pri tem sta uporabila simultano termogravimetrijo in diferencialno vrstično kalorimetrijo (TG-DSC). Vzorce kompozitov sta pripravila z različnim masnim razmerjem lesnega prahu in fenolne smole (PF). Karbonizacijo (pooglenitev) vzorcev sta izvedla pri $800{ }^{\circ} \mathrm{C}, 1000{ }^{\circ} \mathrm{C}$ in $1400{ }^{\circ} \mathrm{C}$. Za karakterizacijo vzorcev kompozitov sta uporabila elementno analizo, Furierjevo transformacijsko infrardečo spektroskopijo (FTIR) in rentgensko difrakcijo (XRD). Elementna analiza je pokazala, da višja temperatura karbonizacije prispeva k višji vsebnosti ogljika, medtem ko višji delež PF v kompozitu privede do manjše vsebnosti ogljika v vzorcih. Rezultati FTIR spektroskopije so nedvoumno pokazali, da višja temperatura karbonizacije prispeva k bolj urejeni strukturi ogljika. To je bilo potrjeno tudi $\mathrm{z}$ XRD. TG-DSC analiza je pokazala, da odpornost kompozita proti oksidaciji narašča z naraščajočo temperaturo karbonizacije, kar je posledica popolnejšega razvoja grafitizacije kompozita pri višjih temperaturah karbonizacije. Po drugi strani povečanje deleža PF v kompozitni mešanici ni prispevalo k izboljšanju oksidacijske odpornosti vzorcev. Navidezna aktivacijska energija je bila visoka v začetnem stadiju reakcij in se je zmanjševala $z$ razvojem termične degradacije. To nakazuje, da je več energije porabljene za dokončanje reakcij oksidacije v začetnem stadiju. Študija je pokazala, da je razviti kompozit na osnovi lesa in PF dobro obstojen proti oksidaciji do $300{ }^{\circ} \mathrm{C}$.

Ključne besede: lesna keramika, odpornost proti oksidaciji, TG, DSC

\section{INTRODUCTION}

Biomass and resin hybrid carbon composites, i.e., woodceramics, are environmentally friendly, light weight, and low cost. Woodceramics are usually obtained through impregnating resin into wood or woody materials, and then carbonizating in vacuum conditions at high temperatures. ${ }^{1-3}$

Woodceramics possess unique characteristics such as high wear and friction resistance, ${ }^{4}$ electromagnetic shielding capacity, ${ }^{5}$ and good mechanical properties. ${ }^{6}$ Previous studies show that porous woodceramics have

*Corresponding author e-mail:

1ptyb@aliyun.com potential applications for catalyst supports, gas filtration, brake pads, etc. due to their hierarchical, biomorphic, and porous structure. ${ }^{7-14}$ The unique three-dimensional natural microstructure of wooderamics cannot be artificially fabricated easily. Moreover, woodceramics have hierarchical pores structures tunable in the microporeto-macropore range. Pan et al. proved that the sugarcane bagasse woodceramics demonstrated a hierarchical porous structure from the micrometer $(0.6-21 \mu \mathrm{m})$ to the nanometer scale $(3.1-9.3 \mathrm{~nm}) .{ }^{14}$ As reported by Yang et al., these hierarchical pore structures were extremely useful in terms of mass transfer and enhancing the reaction pathways, and were anticipated to be effective catalyst media. ${ }^{12}$ 
However, as functional materials, the performances of woodceramics are usually determined by the materials' ability to resist heat. For example, catalytic reactions involving oxidizing conditions above $250{ }^{\circ} \mathrm{C}$ burned off carbon-supported catalysts and reduced its lifespan. ${ }^{15}$ Therefore, the thermal reactivity in air at high temperatures is a crucial characteristic to evaluate woodceramics' proper utilization as catalyst supports for durable applications. Ozao et al. analysed the thermal properties of apple woodceramics and their results showed that the higher carbonization temperature benefited the oxidation resistance of woodceramics. ${ }^{2}$ Oishi et al. reported that the thermal degradation of woodceramics was dependent on the oxygen concentration. ${ }^{16}$

In this paper, to clarify the effects of the processing parameters on the characteristics as well as the oxidation resistance of woodceramics in air, the performances of wood flour/PF woodceramics were investigated using simultanous TG-DSC analysis from room temperature to $700{ }^{\circ} \mathrm{C}$.

\section{EXPERIMENTAL PART}

\subsection{Woodceramics preparation}

The woodceramics were prepared using a laboratory-made fir powder and laboratory-synthesized PF resin. The fir powder used had a moisture content of $8 \%$ and a size passing through a 40-mesh sieve. The PF resin had a solid content of 48-50\%, a viscosity of 30-40 s (TU-4 viscometer), an alkali content of 2.0-2.7 \%, bromides of 16-24\%, and a storage period of at least $60 \mathrm{~d}$ at $5-20{ }^{\circ} \mathrm{C}$.

The composite preform was fabricated by impregnating PF resin into wood powder. The weight ratios of wood powder to PF resin were 40:60, 50:50 and 30:70. The procedures were conducted in three steps, i.e., drying, cold-pressing, and hot-pressing. Samples were then carbonized at temperatures $800{ }^{\circ} \mathrm{C}, 1000{ }^{\circ} \mathrm{C}$, and $1400{ }^{\circ} \mathrm{C}$ in a vacuum sintering furnace under the heating rate of $2{ }^{\circ} \mathrm{C} / \mathrm{min}$.

\subsection{Sample characterization}

Before the thermal analysis, the samples were analyzed to determine the properties that may affect the thermal degradation abilities. The contents of $\mathrm{C}, \mathrm{H}$, and $\mathrm{N}$ of the dried samples were investigated by the CHNS-O Elemental Analyzer (Euro EA 3000-Eurovector Italy) with a combustion temperature at $1020{ }^{\circ} \mathrm{C}$. The FTIR analysis was used to analyze the possible chemical functional groups in the samples using a Nicolet Magna 560 at a resolution of $4 \mathrm{~cm}^{-1}$. The physical characteristics of the prepared woodceramics were identified by the $\mathrm{X}$-ray diffraction (XRD) method on a Rigaku D/max-RB $12 \mathrm{KW} \mathrm{X}$-ray Diffractometer (Rigaku Corporation, Japan) using the nickel-filtered $\mathrm{Cu}-\mathrm{K}_{\alpha}$ radiation in the range of $2 \theta\left(10^{\circ}-90^{\circ}\right)$, where the scanning speed was 2 degree/min.

\subsection{TG-DSC analysis}

The TG-DSC analysis of ca. $10 \mathrm{mg}$ dried material was performed under an air atmosphere in a TG-DSC OLAP analyzer (Netzsch Sta 449c, Deutschland, Germany) with the sensitivity of $0.1 \mu \mathrm{g}$ and $0.1{ }^{\circ} \mathrm{C}$. The samples were heated from $25{ }^{\circ} \mathrm{C}$ to $700{ }^{\circ} \mathrm{C}$ in a $\mathrm{Pt}-\mathrm{Rh}$ crucible. The air flow rate was $30 \mathrm{~mL} / \mathrm{min}$ throughout the whole procedure. The test conditions are shown in Table 1.

Table 1: Test conditions of woodceramic specimens

\begin{tabular}{|c|c|c|c|}
\hline $\begin{array}{c}\text { Sample } \\
\text { number }\end{array}$ & $\begin{array}{c}\text { Weight ratios of } \\
\text { wood powder to } \\
\mathrm{PF}\end{array}$ & $\begin{array}{c}\text { Carbonization } \\
\text { temperature } \\
\left({ }^{\circ} \mathrm{C}\right)\end{array}$ & $\begin{array}{c}\text { Heating rates } \\
\text { of TG/DSC } \\
\left({ }^{\circ} \mathrm{C} / \mathrm{min}\right)\end{array}$ \\
\hline S1 & $40: 60$ & 800 & 2 \\
\hline S2 & $40: 60$ & 800 & 5 \\
\hline S3 & $40: 60$ & 800 & 10 \\
\hline S4 & $40: 60$ & 800 & 20 \\
\hline S5 & $40: 60$ & 1000 & 10 \\
\hline S6 & $40: 60$ & 1400 & 10 \\
\hline S7 & $50: 50$ & 800 & 10 \\
\hline S8 & $30: 70$ & 800 & 10 \\
\hline
\end{tabular}

\subsection{Calculation of activation energy of thermal decom- position reaction}

Using the data of $\mathrm{TG}$, the conversion rate of the samples at any given time/temperature can be obtained with Equation (1):

$$
\alpha=\frac{\left(m_{0}-m_{1}\right)}{\left(m_{0}-m_{\mathrm{f}}\right)}
$$

where, $\alpha$ : conversion rate; $m_{0}$ : initial sample weight; $m_{1}$ : sample weight at any given time; $m_{f}$ : stable sample weight at the end of reaction.

It is assumed that the woodceramics are reactive substances, and the Arrhennius equation could be used to describe the reaction law of the thermal decomposition.

$$
\beta=\frac{d \alpha}{d T}=A \exp \left(-\frac{E}{R T}\right)(1-\alpha)^{n}
$$

where, $\beta$ heating rate, $\mathrm{K} \mathrm{s}^{-1} ; \alpha$ conversion rate; $T$ temperature of sample, $\mathrm{K} ; A$ prefactor; $E$ apparent activation energy, J/mol; $R$ gas constant, $8.314 \mathrm{~J} / \mathrm{mol} \cdot \mathrm{K} ; n$ reaction order.

In order to analyze the kinetic parameters of woodceramics, the apparent activation energy of woodceramics is able to be calculated using four heating rates with the Ozawa method. ${ }^{17}$

The TG data curves obtained at heating rates of $(2,5$, 10, and 20) ${ }^{\circ} \mathrm{C} / \mathrm{min}$ and Equation (3) were used in calculation.

$$
\log \beta+0.4567 \frac{E}{R T}=\text { Const }
$$


If the weight loss rate of formula (3) is a constant, the heating rates $\beta_{1}, \beta_{2}, \beta_{3}$, and $\beta_{4}$ correspond to the temperature $T_{1}, T_{2}, T_{3}$ and $T_{4}$ respectively. A straight line can be drawn using the data of $1 / T$ and $\log \beta$. The apparent activation energy $E$ value can be obtained by calculating the slope of the straight line.

\section{RESULTS AND DISCUSSION}

\subsection{Element analysis of woodceramics}

The contents of $\mathrm{C}, \mathrm{H}$, and $\mathrm{N}$ of woodceramics under different carbonization temperatures as well as different ratios of wood powder to PF were presented in Table 2. As seen, the main component in all samples was carbon. The hydrogen content was low because $\mathrm{H}_{2} \mathrm{O}$, low molecular weight phenolic substances (LMP), and the low molecular weight hydrocarbon $\left(\mathrm{LMH}\right.$, including $\left.\mathrm{CH}_{4}\right)$ were produced during the carbonization process. ${ }^{18}$ With the increase of the PF ratio, the carbon content of samples prepared under $800^{\circ} \mathrm{C}$ declined slightly (S7, S3, and S8) along with lower $\mathrm{H}$ and $\mathrm{N}$ contents. However, under the same weight ratio of wood powder to PF (S3, $\mathrm{S} 5$, and S6), the increased carbonization temperatures contributed to higher carbon contents and lower amounts of heteroatoms. The increase of the carbon content and decrease of the oxygen content with the rise of carbonization temperature revealed that more energy was consumed to deprive the oxygen-containing functional groups.

Table 2: $\mathrm{C}, \mathrm{H}$, and $\mathrm{N}$ contents of woodceramincs

\begin{tabular}{|c|c|c|c|c|c|c|}
\hline $\begin{array}{c}\text { Sample } \\
\text { number }\end{array}$ & $\begin{array}{c}\text { Carboni- } \\
\text { zation tem- } \\
\text { perature } \\
/{ }^{\circ} \mathrm{C}\end{array}$ & $\begin{array}{c}\text { Weight ratio } \\
\text { of wood pow- } \\
\text { der to PF }\end{array}$ & $\mathrm{C} / \%$ & $\mathrm{H} / \%$ & $\mathrm{~N} / \%$ & $\begin{array}{c}\mathrm{O}+ \\
\text { ash } \\
/ \%\end{array}$ \\
\hline S7 & 800 & $50: 50$ & 91.6 & 0.7 & 1.5 & 6.2 \\
\hline S3 & 800 & $40: 60$ & 90.2 & 0.6 & 1.4 & 7.8 \\
\hline S8 & 800 & $30: 70$ & 88.3 & 0.6 & 1.2 & 9.9 \\
\hline S5 & 1000 & $40: 60$ & 95.9 & 0.2 & 1.4 & 2.5 \\
\hline S6 & 1400 & $40: 60$ & 99.5 & 0.0 & 0.0 & 0.5 \\
\hline
\end{tabular}

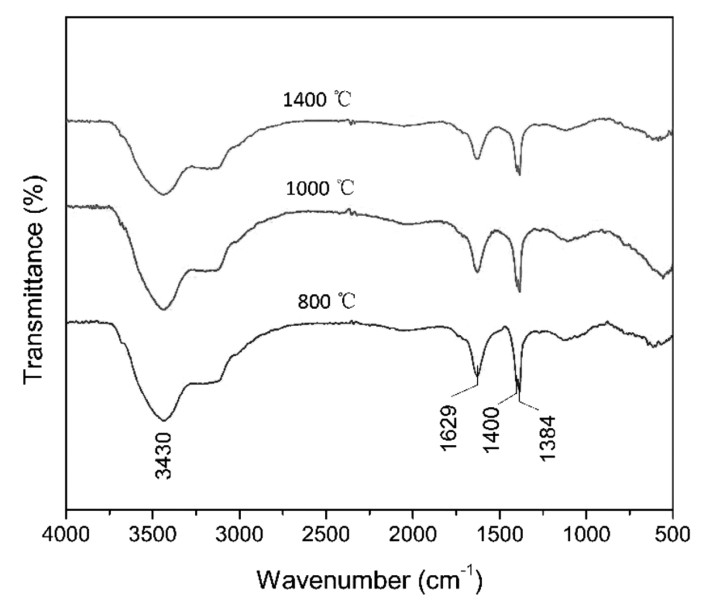

Figure 1: FTIR spectra of woodceramics at different carbonization temperatures (weight ratio of wood powder to PF is 40:60)
Figure 1 shows the FTIR spectra of woodceramics obtained at $800{ }^{\circ} \mathrm{C}, 1000{ }^{\circ} \mathrm{C}$, and $1400{ }^{\circ} \mathrm{C}$, respectively. All the samples displayed a broad $\mathrm{O}-\mathrm{H}$ stretching vibration at around $3430 \mathrm{~cm}^{-1}$. Meanwhile, the aromatic and aliphatic $\mathrm{C}-\mathrm{H}$ asymmetrical stretching vibrations around $3000 \mathrm{~cm}^{-1}$ exhibited a weak trend. $\mathrm{C}=\mathrm{O}$ stretching vibrations between $1750 \mathrm{~cm}^{-1}$ and $1700 \mathrm{~cm}^{-1}$ disappeared with the deprival of oxygen in the samples. A symmetrical peak at $1629 \mathrm{~cm}^{-1}$ was attributed to aromatic $\mathrm{C}=\mathrm{C}$ in-plane stretching vibration. ${ }^{6}$ Strong absorptions at $1400 \mathrm{~cm}^{-1}$ were the results of aromatic stretching vibrations and $-\mathrm{CH}_{3}$ stretching resulted in peaks at $1384 \mathrm{~cm}^{-1} \cdot{ }^{18,19}$ Nevertheless, the vibration strengths of the $\mathrm{C}=\mathrm{C}$ and $-\mathrm{CH}_{3}$ stretching were lowered when the carbonization temperatures were increased. This phenomenon was assocaited with the deprival of low-molecular-weight substances and the diminished carbon and hydrogen contents, as described in Table 2.

Figure 2 presents the XRD intensity curves for the samples prepared under three carbonization temperatures. Two main and a weak wide peaks were detected over the scattering range. The peaks at around $22^{\circ}, 43^{\circ}$, and $80^{\circ}$ correspond to the (002), (10), and (11) peaks, which represented the graphite-like crystalline structure in woodceramics. ${ }^{6}$ The observed broad peaks illustrated the weak regularity of carbon in woodceramics. Furthermore, the data indicated that the amorphous carbons derived from wood powder and $\mathrm{PF}$ resin were hard to be graphitized. However, as the carbonization temperature increased, the (002) peak became sharper and moved to a larger angle slightly. It was shown that the higher carbonization temperature contributed to higher levels of graphitization and lower remaining content of the amorphous carbon. ${ }^{20,21}$

Figure 3 shows the curves of woodceramics prepared with different weight ratios of wood to PF. The contribution of PF content to the graphitization of woodceramics was not obvious. The research conducted by Qian et al. obtained similar results. ${ }^{6}$ Therefore, it can be concluded that carbonization temperature is the vital factor

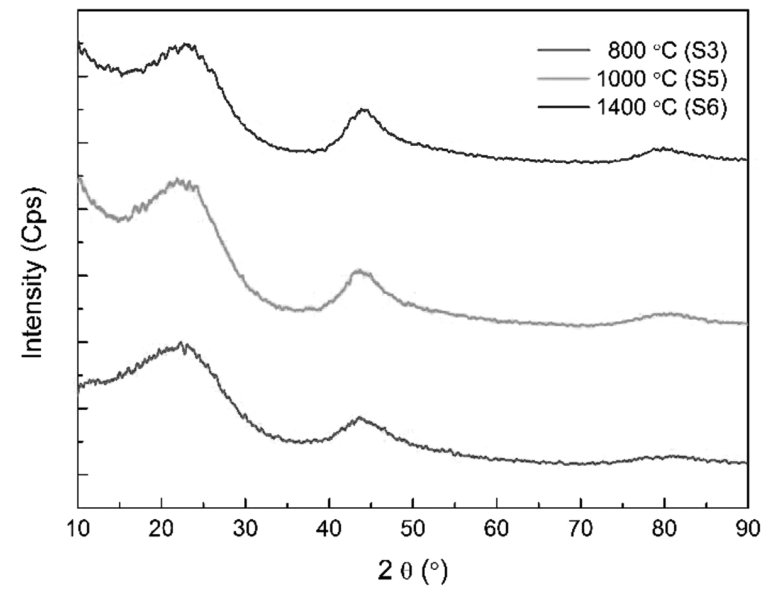

Figure 2: XRD patterns of woodceramics carbonized under different temperatures 


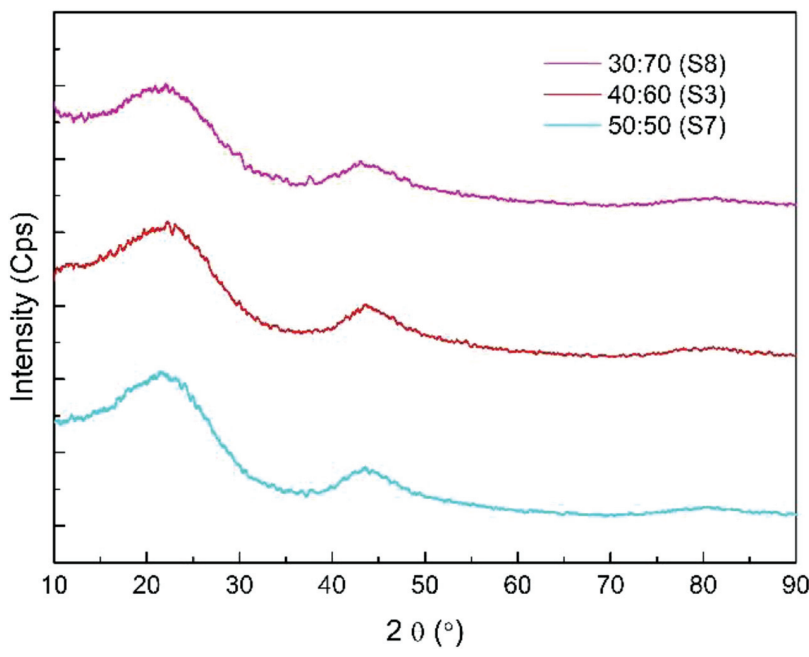

Figure 3: XRD patterns of woodceramics carbonized at $800{ }^{\circ} \mathrm{C}$ (with different weight ratios of wood to PF)

to improve the regularity and crystallite growth of woodceramics.

\subsection{Carbonization temperature vs. oxidation resistance}

Figure 4 depicts the effects of carbonization temperatures $800{ }^{\circ} \mathrm{C}, 1000{ }^{\circ} \mathrm{C}$, and $1400{ }^{\circ} \mathrm{C}$ on the oxidation resistance of woodceramics. The key data of $\mathrm{TG}$ from Figure 4 were summarized and are listed in Table 3.

Table 3: Oxidation resistance of woodeceramics under different carbonization temperatures

\begin{tabular}{|c|c|c|c|}
\hline $\begin{array}{c}\text { Sample } \\
\text { number }\end{array}$ & $\begin{array}{c}\text { Temperature at } \\
9 \% \text { weight } \\
\text { loss }\left({ }^{\circ} \mathrm{C}\right)\end{array}$ & $\begin{array}{c}\text { Temperature at } \\
\text { a starting of } \\
\text { linear variation } \\
\left({ }^{\circ} \mathrm{C}\right)\end{array}$ & $\begin{array}{c}\text { Residual } \\
\text { weight at } \\
700{ }^{\circ} \mathrm{C}(\%)\end{array}$ \\
\hline $\mathrm{S} 3\left(800^{\circ} \mathrm{C}\right)$ & 400 & 430 & 22.8 \\
\hline $\mathrm{S} 5\left(1000^{\circ} \mathrm{C}\right)$ & 565 & 600 & 60.9 \\
\hline $\mathrm{S} 6\left(1400^{\circ} \mathrm{C}\right)$ & 640 & 670 & 77.1 \\
\hline
\end{tabular}

The results indicated that the higher carbonization temperature was beneficial to the oxidation resistance of the woodceramics. As shown in Table 3, when the samples were burned in air till $700{ }^{\circ} \mathrm{C}$, the residues left increased greatly with the growth of carbonization temperature. Moreover, at the first stage, samples carbonized under $800{ }^{\circ} \mathrm{C}, 1000{ }^{\circ} \mathrm{C}$, and $1400{ }^{\circ} \mathrm{C}$ exhibited a linear relation with its $9 \%$ weight loss, being reached at $400{ }^{\circ} \mathrm{C}, 565{ }^{\circ} \mathrm{C}$, and $640{ }^{\circ} \mathrm{C}$, respectively. After a short period of accelerated weight loss, the remains of all samples decreased linearly until the end of the test. An exothermic peak and a small endothermic peak were observed between $400{ }^{\circ} \mathrm{C}$ and $500{ }^{\circ} \mathrm{C}$ on the DSC curve of woodceramics obtained under $800{ }^{\circ} \mathrm{C}$, whereas these peaks disappeared on the other curves.

The weight loss of woodceramics was due to the reaction of carbon with $\mathrm{O}_{2}$. The TG-DSC results demonstrated that the carbonization temperature was a vital factor that affected the oxidation resistance of wood-
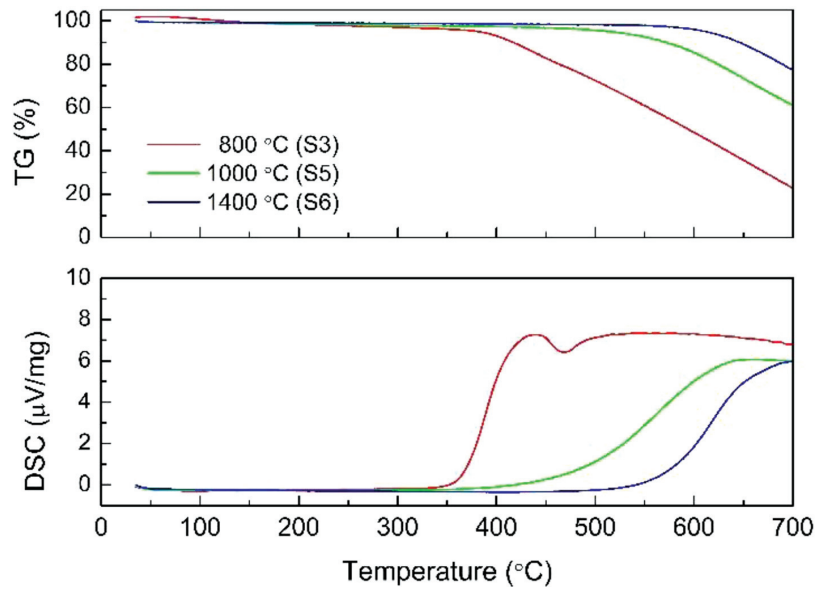

Figure 4: Effect of carbonization temperature on oxidation resistance of woodceramics (Weight ratio of wood to PF was 40:60; Heating rate of TG was $10^{\circ} \mathrm{C} / \mathrm{min}$; Carbonization temperatures were $(800,1000$, and 1400$){ }^{\circ} \mathrm{C}$; Gas environment of TG was Air)

ceramics. With the growth of the carbonization temperature, the starting thermal degradation temperature of woodceramics in air was extended into a higher temperature zone and its oxidation resistance was enhanced. It is well known that the oxidation resistance of woodceramics depends on its reactivity with $\mathrm{O}_{2}$. Based on previous studies involving the oxidation resistance of carbon materials, ${ }^{22,23}$ the oxidation deterioration of woodceramics under high temperatures experiences at least two steps: (1) oxygen diffusing through pores and cracks in the woodceramics to form surface oxides on the carbon surface; (2) reaction between carbon and oxygen to form $\mathrm{CO}_{2}, \mathrm{CO}$, and surface oxygen complexes. Further, it can be assumed that the oxidation resistance of woodceramics is affected by its microstructure, the portions of the surface which are active to react with $\mathrm{O}_{2}$ (also known as active sites), and the reactivity of these active sites. The XRD results in this study illustrated the graphite-like, crystalline amorphous carbon structure of woodceramics, which was consistent with the research conducted by Qian et al. ${ }^{6}$ Nonetheless, the higher carbonization temperature contributed higher regularity of carbon. ${ }^{20,21}$ Although woodceramics inherited the hierarchical porous structure of wood powder, providing abundant oxygen pathways for carbon contacts, ${ }^{5}$ the higher carbonization temperature led to the increase of carbon content and crystallinity, and reduced the internal defects as well as heteroatoms of the woodceramics. Additionally, the carbon crystallization or crystallite growth would abate the reactivity of carbon materials. ${ }^{24}$ Therefore, the oxidation resistance of the woodceramics was improved by increased carbonization temperature.

\subsection{Component ratio vs. oxidation resistance}

Figure 5 shows that, with the increase of PF content, the weight loss of woodceramics (carbonized under 
$800^{\circ} \mathrm{C}$ ) increased slightly. For all samples, the temperature inflection point of weight loss was in the range from $400{ }^{\circ} \mathrm{C}$ to $420{ }^{\circ} \mathrm{C}$. At the temperature inflection point, the sample prepared with the highest weight ratio of wood powder to PF resin exhibited the fastest weight loss among all the samples. At $700{ }^{\circ} \mathrm{C}$, the remaining sample weights were $25.8 \%$ (50:50), $22.8 \%$ (40:60), and $7.6 \%(30: 70)$. The results showed that, with the increase of $\mathrm{PF}$ resin ratio, the oxidation resistance of woodceramics decreased slightly due to the uneven carbonization of $\mathrm{PF}$ in woodceramics under $800{ }^{\circ} \mathrm{C}$. As shown in Table 2, the higher the ratio of PF resin in samples, the lower the carbon content and higher the amounts of heteroatoms were obtained. Therefore, the unstable structure of samples contributed more weight losses when they were heated in air at high temperatures. The results showed that the increase of PF resin ratio was unable to enhance the oxidation resistance of woodceramics when they were fabricated under $800{ }^{\circ} \mathrm{C}$.
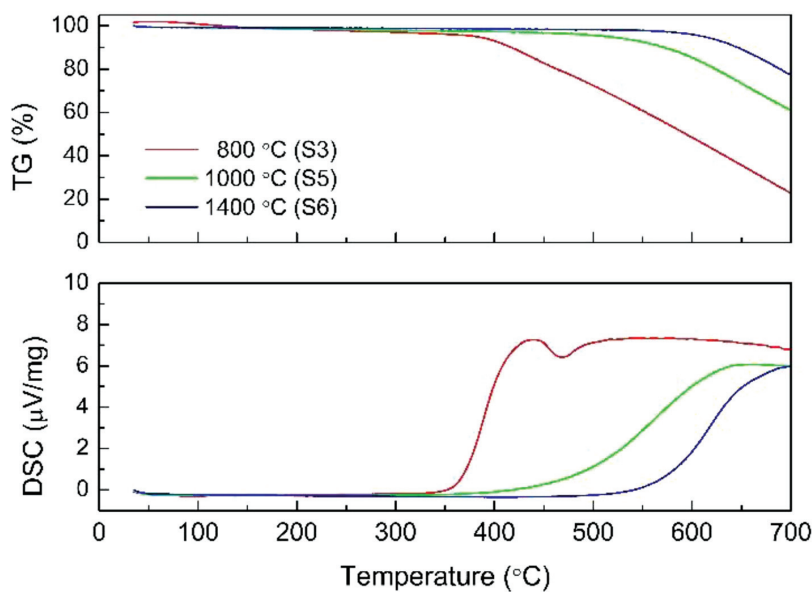

Figure 5: Effect of component ratio on oxidation resistance of woodceramics (Weight ratios of wood to PF are 40:60, 50:50 and 30:70; Heating rate of $\mathrm{TG}$ is $10^{\circ} \mathrm{C} / \mathrm{min}$, carbonization temperature is $800^{\circ} \mathrm{C}$; Gas environment of TG is Air)
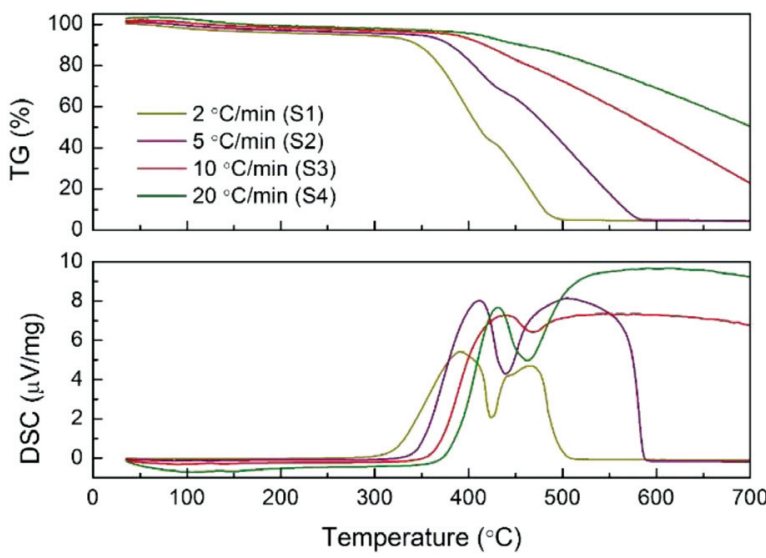

Figure 6: Effect of heating rate on oxidation resistance of woodceramics (weight ratio of wood to $\mathrm{PF}$ is 40:60; Heating rates of TG are $(2,5,10$ and 20$){ }^{\circ} \mathrm{C} / \mathrm{min}$; Carbonization temperature is $800{ }^{\circ} \mathrm{C}$; Gas environment of TG is Air)
The DSC curves in Figure 5 show that a distinct exothermic reaction was exhibited between $370{ }^{\circ} \mathrm{C}$ and $450{ }^{\circ} \mathrm{C}$. With the increase of $\mathrm{PF}$ resin ratio, the curve peaks shifted to the higher temperature range and covered a larger area. This phenomenon showed that the increase of heat release with the rise of PF resin ratio. After that, a small endothermic peak was observed, then the woodceramics continued to have an exothermic reaction. Theoretically, the reaction of carbon and oxygen in air is an exothermic reaction. DSC curves proved that the exothermic reaction was the most important reaction in the thermal decomposition of woodceramics.

\subsection{Heating rate vs. oxidation resistance}

As shown in Figure 6, the heating rate has a significant effect on the thermal decomposition of woodceramics. Before the rapid degradation, all the samples at four heating rates had low weight losses. With the heating rates of $(2,5,10$, and 20$){ }^{\circ} \mathrm{C} / \mathrm{min}$, the starting temperatures of the rapid thermal decompositions were at $(350,380,410$, and 450$){ }^{\circ} \mathrm{C}$, respectively. With the rise of heating rate, the starting temperature of rapid thermal decomposition moved to a higher temperature zone. When the heating rates were at $2{ }^{\circ} \mathrm{C} / \mathrm{min}$ and $5{ }^{\circ} \mathrm{C} / \mathrm{min}$, the thermal decomposition temperatures were terminated at $490{ }^{\circ} \mathrm{C}$ and $570{ }^{\circ} \mathrm{C}$. However, when the woodceramics were treated under heating rates of $10{ }^{\circ} \mathrm{C} / \mathrm{min}$ and $20{ }^{\circ} \mathrm{C} / \mathrm{min}$, their remaining weights were $22.8 \%$ and $50.4 \%$ at $700{ }^{\circ} \mathrm{C}$, respectively, indicating that the thermal decomposition was uncompleted.

The DSC curves in Figure 6 show that the four heating rates of all woodceramics appeared in exothermic, endothermic, and exothermic reaction sequence. It was revealed that there were some active groups in the woodceramics incompletely degraded when they were prepared under $800{ }^{\circ} \mathrm{C}$.

The results showed that the speed of weight loss of woodceramics was reduced with the increase of heating rate. The performances of woodceramic products were
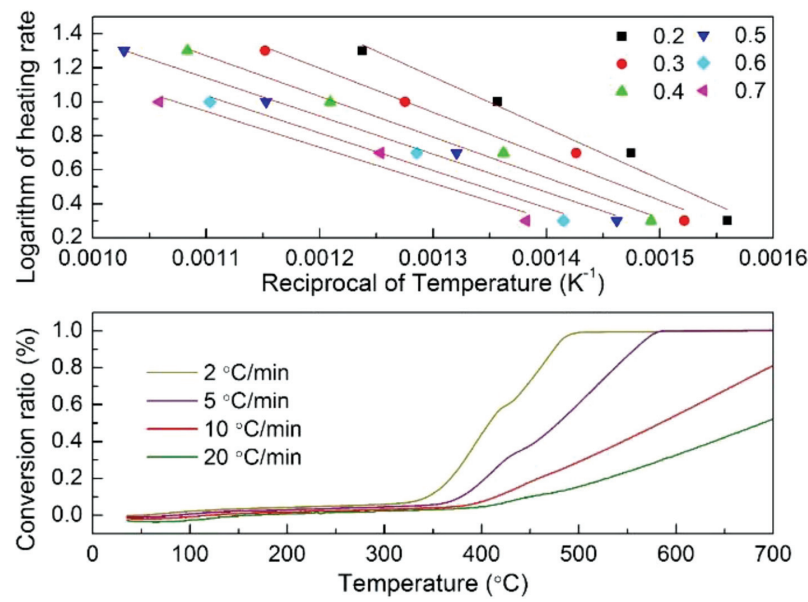

Figure 7: Conversion ratio of woodceramics using different heating rates of $\mathrm{TG}$ 
stable under $300{ }^{\circ} \mathrm{C}$. Therefore, the woodceramics (carbonized under $800{ }^{\circ} \mathrm{C}$, weight ratio of 40:60) are able to be used in air below $300{ }^{\circ} \mathrm{C}$ for a long period of time or be used under an instantaneous high-temperature environment.

\subsection{Apparent activation energy of the thermal decom- position reaction}

The activation energy of a chemical reaction can be used to characterize its reaction rate and analyze the reaction mechanism. Using Equation (1), the conversion ratios of samples (the weight ratio of wood to $\mathrm{PF}$ resin was $40: 60$, the carbonization temperature was $800{ }^{\circ} \mathrm{C}$, and heating rates of TG was $\left(2,5,10\right.$, and 20) ${ }^{\circ} \mathrm{C} / \mathrm{min}$ respectively) at any given time/temperature are shown in Figure 7.

Figure 7 illustrates that at $700{ }^{\circ} \mathrm{C}$, the final conversion ratios of woodceramics were $81.2 \%$ (heating rate of $10{ }^{\circ} \mathrm{C} / \mathrm{min}$ ) and $52.2 \%$ (heating rate of 20 ${ }^{\circ} \mathrm{C} / \mathrm{min}$ ). However, when the heating rates were $2{ }^{\circ} \mathrm{C} / \mathrm{min}$ and $5{ }^{\circ} \mathrm{C} / \mathrm{min}$, the conversions ended at around $500{ }^{\circ} \mathrm{C}$ and $590{ }^{\circ} \mathrm{C}$.

With the increase of the heating rate, the starting temperature of rapid thermal decomposition moved slightly toward higher-temperature zones. Meanwhile, the ending temperature of thermal decomposition increased. Furthermore, through the Equation (2) and (3), the apparent activation energy $E$ value can be obtained by calculating the slope of straight lines as shown in Figure 7. The calculated apparent activation energy are shown in Table 4.

Table 4: Apparent activation energies of thermal oxidation of woodceramics using the Ozawa method ${ }^{17}$

\begin{tabular}{|c|c|c|}
\hline Weight loss $(\%)$ & $\begin{array}{c}\text { Apparent activation } \\
\text { energy, } E(\mathrm{~kJ} / \mathrm{mol})\end{array}$ & $R^{2}$ \\
\hline 20 & 55 & 0.98909 \\
\hline 30 & 47 & 0.98889 \\
\hline 40 & 43.5 & 0.99614 \\
\hline 50 & 40.7 & 0.99624 \\
\hline 60 & 40.1 & 0.98417 \\
\hline 70 & 38.4 & 0.98056 \\
\hline
\end{tabular}

From Table 4 and Figure 7, it was found that the apparent activation energy decreased with the increase of the weight loss of woodceramics. The activation energy was relatively high at the initial phase of the reaction. As the reaction proceeded, the activation energy declined.

The higher activation energy at the initial stage denoted that it was difficult for some carbon molecules to overcome the activation energy barrier to complete oxidation reactions. In another word, more energy were consumed to complete the oxidazation reaction at first, which was consistent with the TG-DSC results.

It is noteworthy that once some carbon molecules can overcome the activation-energy barrier and complete the reaction, they would release energy. The released energy supported other carbon molecules to surpass the energy barrier and lead to a chain reaction. ${ }^{25}$ Consequently, this phenomenon contributed the higher oxidation rate of woodceramics during the second stage. In theory, the heat released from the thermal decomposition reaction can promote the degradation process of woodceramics. Furthermore, with the development of thermal degradation and carbonic oxides emission, the volume of inaccessible pores would diminish, making it easier for oxygen to reach the interior surface of carbon and accelerate the oxidation of woodceramics. ${ }^{26,27}$

\section{CONCLUSIONS}

Woodceramics demonstrated good antioxidant properties in this research. Taking the sample prepared under $800^{\circ} \mathrm{C}$ as an example, due to eliminating moisture and small molecule substance, the thermal weight loss in air at $350{ }^{\circ} \mathrm{C}$ was merely $9 \%$.

The carbonization temperature was an important factor that affected the oxidation resistance of woodceramics. Proliferating the carbonization temperature made it possible to improve the oxidation resistance of the woodceramics. The results highlighted the potential of woodceramics being used as catalyst supports.

The effect of PF resin content on the oxidation resistance was not as apparent as the carbonization temperature. With the increase of PF resin ratio, the thermal weight loss of woodceramics increased, oxidation resistance decreased, and heat release of thermal decomposition increased. Therefore, an optimal ratio of PF resin should be considered if it is desired that the woodceramics can provide sufficient mechanical properties when being used as catalyst supports.

With the growth of TG heating rates, the starting temperature of rapid thermal decomposition increased and slightly shifted to higher temperature zones. Meanwhile, the ending temperatures of oxidation degradation increased.

As the oxidation mass loss increased, the apparent activation energy of woodceramics declined. At the initial stage of reaction, the apparent activation energy of thermo-oxidative decomposition was relatively high. As the reaction progressed, the heat released by decomposition processes played an important role in helping the continuous reaction.

\section{Acknowledgment}

We acknowledge the support from the Fundamental Research Funds for the Central Universities (Grant no. DL12CB07), the Fok Ying-Tong Education Foundation for Young Teachers in the Higher Education Institutions of China (Grant no. 122044). 


\section{REFERENCES}

${ }^{1}$ T. X. Fan, T. Hirose, T. Okabe, D. Zhang, R. Teranisi, M. Yoshimura, Effect of components upon the surface area of woodceramics, J. Porous Mat., 9 (2002), 35-42, doi:10.1023/A:1014399621253

${ }^{2}$ R. Ozao, Y. Nishimoto, W. P. Pan, T. Okabe, Thermoanalytical characterization of carbon/carbon hybrid material, apple woodceramics, Thermochim. Acta, 440 (2006), 75-80, doi:10.1016/j.tca.2005. 10.014

${ }^{3}$ L. Zhang, W. Li, J. Peng, N. Li, J. Pu, S. Zhang, S. Guo, Raman spectroscopic investigation of the woodceramics derived from carbonized tobacco stems/phenolic resin composite, Mater. Design, 29 (2008), 2066-2071, doi:10.1016/j.matdes.2008.04.002

${ }^{4}$ X. Q. Xie, T. X. Fan, B. H. Sun, D. Zhang, T. Sakata, H. Mori, T. Okabe, Dry sliding friction and wear behavior of woodceramics/ Al-Si composites, Mat. Sci. Eng. A-Struct., 342 (2003), 287-293, doi:10.1016/S0921-5093(02)00320-9

${ }^{5}$ Y. Tao, P. Li, S. Q. Shi, Effects of carbonization temperature and component ratio on electromagnetic interference shielding effectiveness of woodceramics, Materials, 9 (2016) 7, 540-548, doi:10.3390/ ma9070540

${ }^{6}$ J. Qian, Z. Jin, J. Wang, Structure and basic properties of woodceramics made from phenolic resin-basswood powder composite, Mat. Sci. Eng. A-Struct., 368 (2004), 71-79, doi:10.1016/j.msea. 2003.09.081

${ }^{7}$ K. Hokkirigawa, T. Okabe, K. Saito, Friction properties of new porous carbon materials: woodceramics, J. Porous Mater., 2 (1996), 237-243, doi:10.1007/BF00488114

${ }^{8}$ T. Okabe, K. Saito, K. Hokkirigawa, New porous carbon materials, woodceramics: development and fundamental properties, J. Porous Mater., 2 (1996), 207-213, doi:10.1007/BF00488110

${ }^{9}$ T. Suda, N. Kondo, T. Okabe, K. Saito, Electrical properties of woodceramics, J. Porous Mater. 6 (1999), 255-258, doi:10.1023/ A: 1009644316468

${ }^{10}$ K. Shibata, T. Okabe, K. Saito, T. Okayama, M. Shimada, A. Yamamura, R. Yamamoto, Electromagnetic shielding properties of woodceramics made from wastepaper, J. Porous Mater., 4 (1997), 269-275, doi:10.1023/A:1009625322670

${ }^{11}$ J. Qian, A. Suo, Y. Yao, Z. Jin, Polyelectrolyte-stabilized glucose biosensor based on woodceramics as electrode, Clin. Biochem., 37 (2004), 155-161, doi:10.1016/j.clinbiochem.2003.10.013

${ }^{12}$ Y. Yang, K. Chiang, N. Burke, Porous carbon-supported catalysts for energy and environmental applications: A short review, Catal. Today, 178 (2011), 197-205, doi:10.1016/j.cattod.2011.08.028

${ }^{13}$ G. Bantsis, M. Betsiou, A. Bourliva, T. Yioultsis, C. Sikalidis, Synthesis of porous iron oxide ceramics using Greek wooden templates and mill scale waste for EMI applications, Ceram. Int., 38 (2012), 721-729, doi:10.1016/j.ceramint.2011.07.064
${ }^{14}$ J. Pan, X. Cheng, X. Yan, C. Zhang, Preparation and hierarchical porous structure of biomorphic woodceramics from sugarcane bagasse, J. Eur. Ceram. Soc. 33 (2013), 575-581, doi:10.1016/j.jeurceramsoc. 2012.09.006

${ }^{15} \mathrm{R}$. Francisco, The role of carbon materials in heterogeneous catalysis, Carbon, 36 (1998), 159-175, doi:10.1016/S0008-6223(97) 00173-5

${ }^{16}$ Y. Oishi, M. Kano, K. Morita, Y. Yamauchi, M. Morita, Thermal degradation of woodceramics under different oxygen concentration, Mater. Trans., 44 (2003), 1163-1166, doi:10.2320/matertrans.44. 1163

${ }^{17}$ T. Ozawa. A new method of analyzing thermogravimetric data, B. Chem. Soc. Jpn., 38 (1965) 11, 1881-1886, doi:10.1246/bcsj.38. 1881

${ }^{18} \mathrm{~S}$. Li, Y. Tao, J. Li, Y. Liu, Pyrolysis of PF resin with TG-DSC-FTIR, J. Northeast Forestry University, 35 (2007) 6, 56-58, doi:10.4028/ www.scientific.net/AMR.631-632.104

${ }^{19}$ S. Kloss, F. Zehetner, A. Dellantonio, R. Hamid, F. Ottner, V. Liedtke, M. Schwanninger, M. H. Gerzabek, G. Soja. Characterization of slow pyrolysis biochars: effects of feedstocks and pyrolysis temperature on biochar properties, J. of Environ. Qual., 41 (2012) 4 , 990-1000, doi:10.2134/jeq2011.0070

${ }^{20}$ A. Arenillas, F. Rubiera, C. Pevida, C. O. Ania, J. J. Pis, Relationship between structure and reactivity of carbonaceous materials, J. Therm. Anal. Calorim., 76 (2004), 593-602, doi:10.1023/B:JTAN. 0000028038.34976 .83

${ }^{21}$ L. Lu, C. Kong, V. Sahajwalla, D. Harris, Char structural ordering during pyrolysis and combustion and its influence on char reactivity, Fuel, 81 (2002), 1215-1225, doi:10.1016/S0016-2361(02)00035-2

${ }^{22}$ R. O. Lussow, F. J. Vastola, P. L. Walker Jr., Kinetics of oxygen interaction with graphon between 450 and $675{ }^{\circ} \mathrm{C}$, Carbon, 5 (1967), 591-602, doi:10.1016/0008-6223(67)90039-5

${ }^{23}$ K. L. Luthra, Oxidation of carbon/carbon composites-a theoretical analysis, Carbon, 26 (1988), 217-224, doi:10.1016/00086223(88)90040-1

${ }^{24} \mathrm{X} . \mathrm{Xu}, \mathrm{Q}$. Chen, H. Fan, The influence of high-temperature crystallite growth and petrography of pulverized char on combustion characteristics, Fuel, 82 (2003) 7, 853-858, doi:10.1016/S00162361(02)00380-0

${ }^{25}$ S. R. Kelemen, H. Freund, A comparison of O2 and CO2 oxidation of glassy carbon surfaces, Carbon, 23 (1985) 6, 723-729, doi:10.1016/0008-6223(85)90234-9

${ }^{26}$ S. J. Gregg, R. F. S. Tyson, The kinetics of oxidation of carbon and graphite by oxygen at $500^{\circ}-600^{\circ}$, Carbon, 3 (1965) 1, 39-42, doi:10.1016/0008-6223(65)90025-4

${ }^{27}$ V. Z. Shemet, A. P. Pomytkin, V. S. Neshpor, High-temperature oxidation behavior of carbon materials in air, Carbon, 31 (1993) 1 , 1-6, doi:10.1016/0008-6223(93)90148-4 